ELORE (ISSN 1456-3010), vol. 19 - 1/2012.

Julkaisija: Suomen Kansantietouden Tutkijain Seura ry.

[http://www.elore.fi/arkisto/1_12/saarinen.pdf]

KIRJA-ARVIO

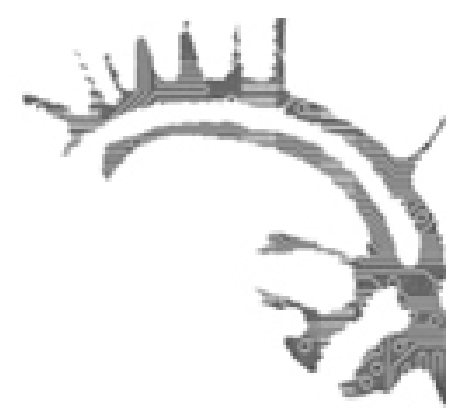

\title{
NAISTEN HOUSUT
}

\section{MAAILMANLOPUN ENNE VAI KÄYTÄNNÖLLINEN PUVUNPARSI?}

TURUNEN, ARJA 2011: Hame, housut, hamehousut! Vai mikä on tulevaisuutemme? Naisten päällyshousujen käyttöä koskevat pukeutumisohjeet ja niissä rakentuvat naiseuden ibanteet suomalaisissa naistenlehdissä 1889-1945. Kansatieteellinen arkisto 53. Helsinki: Suomen muinaismuistoyhdistys. 458 sivua.

\section{Tuija Saarinen}

Housut ovat länsimaisessa pukeutumisessa olleet perinteisesti miesten vaate ja samalla maskuliinisuuden symboli. Ei ihme, että housujen yleistyminen osaksi naistenkin vaatetusta herätti laajaa keskustelua ja kytkeytyy viime kädessä myös naisen yhteiskunnallisen aseman muutokseen.

Arja Turusen tutkimuksessa Hame, housut, hamehousut! selviää, mistä suomalaisissa naistenlehdissä keskusteltiin 1800-1900-lukujen vaihteen ja toisen maailmansodan välisenä aikana, kun niissä käsiteltiin naisten päällyshousujen käyttöä. Housut alkoivat tuolloin tulla osaksi naisten vaatetusta Suomessa, mikä herätti keskustelua niin puolesta kuin vastaan. Turusen lähtökohtana on ollut ajatus siitä, että naisten housujen käyttöä koskevat pukeutumisohjeet ja muu keskustelu eivät kerro ainoastaan pukeutumisen ihanteista ja käytänteistä vaan myös niistä merkityksistä, joita naiseus tuolloin sai. Pukeutumisohjeet kuvasivat myös sitä, miten sukupuolten välinen suhde ja naisten yhteiskunnallinen asema ymmärrettiin.

Vaatteet ovat yksi kontrollin ja vallan käytön keino. Ne rajoittavat tapoja, joilla ruumis voi liikkua ja joilla sitä voi käyttää. Pukeutumiskulttuuri koostuu useista eri osa-alueista. Ensinnä siihen kuuluvat vaatteet materiaalisina objekteina sekä muu pukeutumiseksi luokiteltava ruumiin muokkaustapa. Toiseksi pukeutumiskulttuuri koostuu pukeutumisen diskursseista - arvoista ja normeista eli niistä tavoista, joilla pukeutumista merkityksellistetään. Kolmanneksi siihen sisältyvät pukeutumisen käy- 
Tuija Saarinen: maailmanlopun enne vai käytännöllinen puvunparsi?

tänteet: pukeutumisen tavat ja ne käytännön toimet, joita pukeminen ja pukeutuminen pitävät sisällään.

Turusen tutkimus on luonteeltaan monitieteinen. Se yhdistää etnologian, pukeutumistutkimuksen, sukupuolentutkimuksen ja mediatutkimuksen lähestymistapoja, menetelmiä ja teoreettisia keskusteluja. Sen lähtökohtana on etnologinen kiinnostus arkiseen pukeutumiseen ja sen merkitykseen kulttuuristen merkitysten konstruoijana ja heijastajana. Tutkimus kohdistuu sukupuolten rajoja rikkovaan pukeutumiseen ja etsii vastauksia naistenlehdistä: Marttaliiton julkaisemasta Emäntälebdestä, naisliikkeen Koti ja Yhteiskunta-lehdestä, Lotta Svärd-lehdestä, kaupallisista Kotiliedestä ja Suomen Kuvalehdestä sekä Työläisnaisliiton Toverittaresta. Naistenlehtiä on käytetty tutkimusaineistoina turhan harvoin ottaen huomioon, että ne osallistuvat myös vallankäyttöön heijastaessaan ja tuottaessaan pukeutumista koskevia diskursseja.

Turusen lähdeaineistoina käyttämissä, vuosina 1889-1945 ilmestyneissä naistenlehdissä annetaan merkityksiä vaatteiden materiaaleille ja valmistustavoille ja arvotetaan niitä. Samoin lehdissä annetaan pukeutumisneuvoja tietynlaisiin pukeutumisdiskursseihin nojautuen ja neuvotaan tietynlaisia pukeutumistapoja ja -rutiineja. Lehdissä onkin käsitelty asioita, joista muissa lähteissä ei puhuta tai joista muutoin on vähän tietoa. Tutkimuksessa sovelletaan diskurssitutkimuksen näkökulmaa naistenlehtien konstruktiivisen luonteen vuoksi. Lehdet eivät heijasta todellisuutta sellaisenaan, vaan rakentavat sitä kielellisten valintojen kautta.

\section{Pukeutuminen ja sukupuoli}

Vaatteiden ja pukeutumisen sukupuolesta kertovat ominaisuudet ovat kulttuuri- ja aikasidonnaisia. Myös muodin olemukseen kuuluu jatkuva sukupuolen uudelleenmäärittely. Meidän aikanamme lapset sosiaalistetaan sukupuoleensa pukemalla heitä jo vauvana punaisiin tai sinisiin vaatteisiin. Vauvan vaatteiden väri toimii aikuisille merkkinä, jonka mukaan lapseen suhtaudutaan tai hänen oletetaan käyttäytyvän. Myöhemmin ihminen tunnistetaan mieheksi tai naiseksi pukeutumisen avulla. Vaatteella on sen vuoksi väliä, valtaa ja voimaa. Pukeutuminen kokonaisuudessaan tarjoaa hyvää aineistoa sukupuolen kulttuurisen ja sosiaalisen rakentumisen tarkasteluun.

Myös erilainen tilannepukeutuminen noudattaa sukupuolijakoa. Työpukeutuminen on osa hallinnon institutionaalisia ja yrityskohtaisia strategioita. Tietynlaisten pukeutumisdiskurssien ja -strategioiden avulla yritykset kontrolloivat työntekijöittensä ruumiita.

\section{KANSANNAINEN VASTUSTAA UUTUUKSIA}

Monia uutuuksia vastustettiin niin sanotuissa kansan syvissä riveissä. Housutkaan eivät yleistyneet koko kansan vaatetukseksi yhdessä vuosikymmenessä, vaan pukeutumiskulttuurin muutos vaati aikaa. Alushousujen historia on hyvä esimerkki siitä, kuinka hidas muutosprosessi voi olla. 
Tuija Saarinen: maailmanlopun enne vai käytännöllinen puvunparsi?

Kansan pukeutuminen ei Suomessa ollut vielä 1800-luvulla erikoistunut alus- ja päällysvaatteiksi. Samaa paitaa voitiin käyttää yötä päivää - vuodenajasta riippumatta. Miehillä saattoi olla jalassaan vain yhdet housut, sillä alushousut tulivat osaksi miesten vaatepartta vasta 1800 - ja 1900-lukujen vaihteessa. Naisten alushousut tulivat ensimmäisinä käyttöön säätyläisten parissa 1810-luvulla. Käsityöläisillä ne yleistyivät 1800-luvun puolivälissä, mutta maaseudulla muutoin vasta 1880- ja 1890-luvuilla. Paikoitellen alushousuja alettiin käyttää vasta vuosisadan vaihteessa tai 1910-luvulla; Savossa ja sitä pohjoisempana vasta 1920- ja 1930-luvulla. Tiedetään, että jotkut iäkkäät naiset olivat ilman alushousuja vielä 1960-luvullakin.

Alushousut yleistyivät hämmästyttävän hitaasti. Niitä vastustettiin muun muassa ylellisyytenä ja turhamaisena säätyläisten tapojen tavoitteluna. Uutuustuotteiden ja -vaatteiden hankinta tuomittiin turhaksi rahankulutukseksi ja hienosteluksi. Alushousujen arveltiin kertovan materiaalisten arvojen asettamisesta henkisten arvojen edelle: kaikki maallinen oli turhaa ja siksi syntiä. Alushousuja pidettiin myös moraalittomina ja niiden katsottiin viittaavan "puolimaailman naisiin" eli prostituoituihin.

Alushousujen yleistyminen liittyy myös naisten elämänpiirin laajenemiseen kotipirtin ulkopuolelle. Lämpimissä hirsituvissa alushousuille ei ollut tarvetta, sillä lyhyt pistäytyminen esimerkiksi kaivolla tai navetassa hoitui ilmankin. Housuttomuudesta tuli ongelma vasta, kun tyttöjen piti tarjeta pitkillä koulumatkoilla tai kun naiset joutuivat ulkotöihin kauas kotoa. Naisethan joutuivat paikoitellen osallistumaan metsän kaatoon ja rahdinajoon. Tuolloin saatettiin tilapäisesti käyttää miesten alushousuja. 1900-luvulla tapahtunut hameiden lyheneminen teki viimein erillisten alushousujen käytön välttämättömäksi, kun pitkä hameenhelma ei enää ollut ruumiin suojana. Alushousujen valmistaminen opittiin usein koulun käsitöissä. Vielä talvisodan aikana naisia neuvottiin kunnon alushousujen teossa ja muistutettiin lämpimänä pysymisen tärkeydestä yhteiskunnallisia tehtäviä suoritettaessa. Siten alushousujen käytöstä tuli isänmaata palveleva teko, jolla nainen turvasi oman ja tulevan sukupolven terveyden sekä lujitti isänmaan puolustustahtoa ja -voimaa.

\section{PÄÄllyshousut}

Naisten päällyshousujen käytöstä on olemassa vain vähän tutkimustietoa. Tiedetään, että Suomessakin on tuomittu naisia oikeudessa housujen käytöstä. Maaseudulla on elänyt miesten vaatteisiin eli housuihin pukeutuneita ja miesten töitä tehneitä miesmäisiä naisia. Kansan naiset ovat myös voineet pukeutua satunnaisesti miesten housuihin esimerkiksi riihessä, jossa käytettiin yleensä vanhoja ja kuluneita vaatteita. Housujen käyttöä ei silti katsottu hyvällä, sillä vanhan kansan mielestä naisten housujen käyttö oli maailmanlopun enne.

Miesten housut olivat kansanomaisessa kulttuurissa vahvoja symbolisia ja maagisia merkityksiä sisältänyt vaate, johon katsottiin sisältyvän miehen sukupuolielimissä sijaitseva miehen väki. Esimerkiksi karjan suojelemiseksi lehmiä saatettiin läiskiä miesten housuilla. Samanlainen väki sijaitsi naisen sukupuolielimissä. Sukupuolielinten paljastaminen oli keino käyttää naisen väkeä esimerkiksi lasten tai karjan suojelemi- 
Tuija Saarinen: maailmanlopun enne vai käytännöllinen puvunparsi?

seksi tai kalaonnen takaamiseksi. Pois kotoa lähdettäessä äiti suojeli lapsensa matkan ajaksi harakoimalla nämä eli harppaamalla lattialle makaamaan asetettujen lasten yli. Laskettaessa kesällä lehmiä ja lampaita laitumelle nainen suojeli ne virtsaamalla niiden päälle. Siksi ei ollutkaan samantekevää, miten ja millä naisen alaruumis peitettiin. Naisten housujen käytöllä on ollut myös poliittisia merkityksiä. Vuoden 1918 sisällissodan aikaan punakaartin aseelliseen toimintaan osallistuneet naiset herättivät housupuvuillaan ja polkkatukallaan huomiota niin punakaartilaisten kuin valkoistenkin keskuudessa. Housuja käytettiin, koska ne olivat käytännöllisiä. Samalla niitä pidettiin myös aatteellisena valintana, vallankumouksen symbolina. Myöhemmin Lotta Svärd -järjestö kielsikin housujen käytön jäseniltään ja sääti tarkkaan hameen helman pituuden.

\section{ELÄMÄNPIIRIN LAAJENEMINEN LISÄSI HOUSUJEN SUOSIOTA}

Housujen käyttö tuli osaksi naisten pukeutumista urheilupukeutumisen kautta. Housuja on käytetty urheiluvaatteina vähitellen 1880-luvulta alkaen. 1900-luvun alussa housujen käyttö edesauttoi perinteisten sukupuoliroolien asteittaista murtumista, sillä naisten urheiluharrastusten yleistyminen tapahtui muiden naiseutta koskevien käsitysten muutosten kanssa: naista oli pidetty heikkona ja hauraana ja muun muassa hänen haavoittuvaista suvunjatkamiskykyään varjeltiin. Vähitellen yleistyi ajatus, että urheilu edistää naisten terveyttä. Urheilulla oli aikakauden hengen mukainen rodun parantamiseen tähtäävä tavoite, jota myös puvun oli palveltava. Liikkumisen konkreettiset esteet ylitettiin, kun hame ei estänyt liikkeiden suorittamista. Housut antoivat tilaa liikkua ja mahdollistivat esimerkiksi hiihtämisen. Housujen käyttö talvi-, kesäurheilu- ja rantavaatteina yleistyi 1930-luvulla. Urheilun oikeissa vaatteissa katsottiin kohottavan kansanterveyttä ja vahvistavan suomalaista rotua.

Naisten housujen yleistymisen taustalla toimi monta vaikuttajaa. Painotettiin terveyttä, hygieenisyyttä ja käytännöllisyyttä. Esimerkiksi naisasialiikkeen tavoitteena oli muuttaa pukeutumista käytännöllisemmäksi, terveellisemmäksi ja mukavammaksi. Käytössä ollut korsetti kiristi ja jopa lääketieteellisissä julkaisuissa huolehdittiin sen vaikutuksesta sisäelimiin ja naisen terveyteen. Hame oli myös painava, epäkäytännöllinen ja jopa vaarallinen tiettyjä töitä tehtäessä. Tehdastyössä laajojen helmojen tarttuminen esimerkiksi koneiden rattaisiin oli todellinen uhka. 1800-luvun lopussa sallittiinkin naisten käytännöllinen työpukeutuminen, mutta housujen soveltuvuudesta keskusteltiin vielä vuosikymmeniä. Pitkään kannettiin huolta siitä, sopiiko naisen esiintyä työpuvussa (housuissa) esimerkiksi julkisissa kulkuvälineissä. Olihan housupukuinen nainen korostuneesti sukupuolieroa haastava ilmestys. Housujen käytännöllisyys vei viimein voiton ja muutti samalla passiivisena ja heikkona pidetyn naisen aktiiviseksi, itsenäisesti liikkuvaksi toimijaksi.

Perinteentutkija, filosofian tohtori Tuija Saarinen, Itä-Suomen yliopisto, Joensuu. 